\title{
Akut Alt Solunum Yolu Enfeksiyonu Tanılı Çocuk Hastalarda D Vitamini Düzeylerinin Yaş, Cinsiyet ve Mevsimlere Göre Değişimi
}

\section{Change of Vitamin D level in Children with Acute Lower Respiratory Tract Infection According to Age, Gender and Season}

\author{
Kamile Arıkan $^{1}$ (D) Aslı Çelebi Tayfur ${ }^{2}$ (D)
}

${ }^{1}$ Sağlık Bilimleri Üniversitesi, İzmir Behçet Uz Çocuk Hastanesi, Çocuk Enfeksiyon Kliniği, İzmir, Türkiye

${ }^{2}$ Sağılık Bilimleri Üniversitesi, Ankara Keçiören Eğitim ve Araştırma Hastanesi, Çocuk Nefroloji Kliniği Ankara, Türkiye

ORCID ID: K.A 0000-0002-1610-4395; A.Ç.T. 0000-0002-6280-4587

Attf/Citation: Arikan K, Celebi Tayfur A. Akut alt solunum yolu enfeksiyonu tanılı çocuk hastalarda d vitamini düzeylerinin yaş, cinsiyet ve mevsimlere göre değişimi. Çocuk Dergisi - Journal of Child 2021;21(2):94-98. https://doi.org/10.26650/jchild.2021.2.798556

öz

Amaç: Akut alt solunum yolu enfeksiyonları (ASE) 5 yaş altı çocuklardaki ölümlerinin en sık nedenini oluşturur. Bu çalışmada akut ASE tanısı alan hastalarda serum $25(\mathrm{OH})$ vitamin D düzeylerinin yaş gruplarına göre incelenmesi planlanmıştır.

Metod: Çalışmaya Sağılık Bilimleri Üniversitesi Ankara Keçiören Eğitim ve Araştırma Hastanesi'nde Temmuz 2018-Temmuz 2019 tarihleri arasında ASE tanısı ile izlenen 1 ay-18 yaş aralığında çocuk hastalar dahil edildi. Hastaların hastaneye başvuru şikayeti, sosyodemografik özellikleri, serum $25(\mathrm{OH})$ vitamin D düzeyi, hastaneye yatı̧̧ öyküsü ve yatış süresi kaydedildi. Bulgular: Çalışmaya ortanca yaşı 4 yaş (1 ay-17 yaş) olan 65'i $(\% 61,9)$ erkek (E/K:1,6) toplam 105 hasta dahil edildi. Yirmi dokuz $(\% 27,6)$ hasta yatırılarak, $76(\% 72,6)$ hasta ayaktan takip edildi. Hastaların $44^{\prime}$ ü viral akut alt solunum yolu enfeksiyonu, $61^{\prime} \mathrm{i}$ bakteriyel akut alt solunum yolu enfeksiyonu tanısı ile izlenmiştir. Serum $25(\mathrm{OH})$ vitamin $D$ düzeyi hastaların 63 'ünde düşük ( $<20 \mathrm{ng} / \mathrm{mL}), 42$ 'sinde normal $(\geq 20 \mathrm{ng} / \mathrm{mL}$ ) olarak saptandı. Yirmi dört $(\% 22,9)$ hastanın serum $25(\mathrm{OH})$ vitamin $\mathrm{D}$ düzeyi $<12 \mathrm{ng} / \mathrm{mL}, 37$ $(\% 35,2)$ hastanın $12-20 \mathrm{ng} / \mathrm{mL}$ arasında, $44(\% 41,9)$ hastanın $>20 \mathrm{ng} / \mathrm{mL}$ olarak saptandı.

Çalışmaya dahil edilen 1 yaş altındaki 32 hastanın kış mevsiminde doğanlarında tanı anında ortanca serum $25(\mathrm{OH})$ vitamin $\mathrm{D}$ düzeyleri, diğer mevsimlerde doğan 1 yaş altındaki hastalara göre daha düşük saptandı. Bir yaşından küçük ve akut ASE nedeni ile yatıılarak tedavi edilen hastaların serum ortanca $25(\mathrm{OH})$ vitamin $\mathrm{D}$ düzeyi $[25,9 \mathrm{ng} / \mathrm{mL}(1,7-87,7)]$, ayaktan tedavi edilen 1 yaşından küçük hastalarınkine $[42,1 \mathrm{ng} / \mathrm{mL}(16,6-62,6)]$ göre daha düşük bulundu $(p=0,035)$.

Sonuç: Çalışmamızda akut ASE tanısı ile izlenen hastalarda serum vitamin $D$ eksikliği/yetersizliğinin sık olarak saptanması, vitamin $D$ düşüklüğünün çocuklarda akut ASE'nin gelişiminde ve ilerlemesinde önemli bir risk faktörü olduğunu düşündürmüştür.

\section{ABSTRACT}

Objective: Lower respiratory tract infections (LRTI) are the most common reason of mortality for under 5 years old. We aimed to examine serum 25 $(\mathrm{OH})$ vitamin D level of children with LRTI according to age, time of admission and gender.

Methods: Children between 1 months- 18 years of age with a diagnosis of LRTI admitted to the Health Science University Keciören Research and Training Hospital between July 2018 and July 2019 were included. Sociodemographic characteristics, serum $25(\mathrm{OH})$ vitamin D levels, history of recurrent LRTI, and hospitalisation time were recorded.

Results: A total of 105 patients, 65 (61.9\%) male (M/F:1.6) with a median age of 4 years ( 1 month-17 years) were included. Twenty nine patients (27.6\%) were hospitalised and $76(72.6 \%)$ patients were outpatients. Of them, 44 patients were diagnosed with viral acute lower respiratory tract infection and the remaining 61 with bacterial acute lower respiratory tract infection. Serum $25(\mathrm{OH})$ vitamin D level was low in 63 patients $(<20 \mathrm{ng} /$ $\mathrm{mL}$ ), and normal in 42 patients ( $\geq 20 \mathrm{ng} / \mathrm{mL}$ ). In 24 patients $(22.9 \%)$, serum $25(\mathrm{OH})$ vitamin $\mathrm{D}$ level was $<12 \mathrm{ng} / \mathrm{mL}$, in $37(35.2 \%)$ patients, it was in $12-20 \mathrm{ng} / \mathrm{mL}$, and in 44 (41.9\%) patients, $>20 \mathrm{ng} / \mathrm{mL}$. In 32 patients under 1 year old of age, median serum $25(\mathrm{OH})$ vitamin $D$ levels were lower in patients born in winter compared to patients born in other seasons. The serum median $25(\mathrm{OH})$ vitamin $\mathrm{D}$ level of hospitalised children under 1 year old of age was statistically significantly lower than in outpatients of the same age group, [25.9 ng/mL (1.7-87.7) versus $42.1 \mathrm{ng} / \mathrm{mL}$ (16.662.6), $p=0.035$ ].

Conclusion: We conclude that, vitamin $D$ deficiency/insufficiency may be a risk factor for LRTI presentation, recurrence and outcome in children.

Keywords: Lower respiratory tract infection, serum $25(\mathrm{OH})$ vitamin $D$ level, recurrent pneumonia, vitamin D insufficiency 


\section{GiRiş}

Akut alt solunum yolu enfeksiyonları (ASE) 5 yaş alt çocuklardaki ölüm nedenlerinin \%15'ini oluşturur. Dünya Sağlık Örgütü (DSÖ) verilerine göre 2017 yılında 800.000 civarı çocuk ASE nedeniyle hayatını kaybetmiştir. ASE'ye zemin hazırlayan etmenler yaş (<1 yaş), düşük doğum ağırlığı, erken doğum, beslenme yetersizliği, altta yatan kronik hastalık, anne sütü ile beslenememe, düşük sosyoekonomik düzey, kalabalık yaşam koşulları (geniş aile, kreş bakımı, vb.), sağlık hizmetlerine ulaşamama, anne yaşı ve annenin eğitimi, başta sigara olmak üzere ev içi ve dış ortam hava kirliliği, yetersiz bağışıklama ve $D$ vitamini eksikliğidir (1,2).

D vitamini; yağda eriyen vitaminler arasında yer almakta olup aynı zamanda endojen olarak uygun biyolojik ortamda sentezlenebildikleri için hormon ve hormon öncüleri olan bir grup steroldür. D vitamini birçok hücre fonksiyonu, çoğalma, farkIılaşma, apoptozis ve anjiogenezis ile ilgili 200'den fazla geni kontrol etmektedir (3-5). D vitamini reseptörlerinin makrofajlar, dendritik hücreler, aktive $T$ ve B lenfositlerde varlığının saptanmasıyla birlikte $D$ vitamini ve aktif metaboliti olan $1.25(\mathrm{OH})_{2} D$ vitamininin bağışıklık fonksiyonlarının iyileşmesinde ve enflamasyon kontrolünde önemli rolü olduğu düşünülmektedir (6-9).

Vitamin D eksikliği veya yetersizliğinin yaygın kanserler, kardiyovasküler hastalıklar, metabolik sendrom, enfeksiyöz ve otoimmun hastalıklar gibi birçok kronik hastalıkla ilişki içinde olduğu bulunmuştur (7). Serum $25(\mathrm{OH})$ vitamin D düzeyi, vitamin D'nin nutrisyonel durumunu değerlendirmek amacı ile uluslararası bir standart test olarak kullanılmaktadır. Literatürde çocuklarda solunum yolu enfeksiyonu insidansı ve $25(\mathrm{OH})$ vitamin D düzeyi arasında ilişkiyi gösteren çalışmalar bulunmakla birlikte serum $25(\mathrm{OH})$ vitamin D düzeyinin yaşa göre değişimlerini inceleyen az sayıda çalışma mevcuttur.

Bu çalışmada hastanemizde 2018-2019 yılları arasında akut ASE tanısı ile izlenen hastaların serum $25(\mathrm{OH})$ vitamin D düzeyinin yaş gruplarına göre değerlendirilmesi planlanmıştır.

\section{GEREÇ VE YÖNTEM}

Çalışmaya Temmuz 2018-Temmuz 2019 tarihleri arasında Sağlık Bilimleri Üniversitesi Ankara Keçiören Eğitim ve Araştırma Hastanesi'de akut ASE tanısı (bronşiolit, bronkopnömoni ve pnömoni) ile izlenen 1 ay-18 yaş aralığında hastalar dahil edildi. Yenidoğan olgular çalışmaya dahil edilmedi.Hastaların hastaneye başvuru tarihi, doğum tarihi, demografik özellikleri, hastanede yatış öyküsü olup olmadığı, hastanede yatış öyküsü olanların yatıs süreleri ve serum $25(\mathrm{OH})$ vitamin $D$ düzeyleri kaydedilmiştir. $25(\mathrm{OH})$ vitamin D düzeyi Shimadzu aygıtında, HPLC tekniğiyle, ImmunChrom (IC3401rp) kitiyle çalışıldı. Serum $25(\mathrm{OH})$ vitamin $D$ düzeyinin $<12 \mathrm{ng} / \mathrm{ml}$ olması $D$ vitamini eksikliği, $12-20 \mathrm{ng} / \mathrm{mL}$ olması $D$ vitamini yetersizliği olarak tanımlandı; >20 ng/mL olması normal olarak kabul edildi. Son üç aydır $25(\mathrm{OH})$ D vitamini desteği alan hastalar çalışma dışı bırakıldı. Hastaların serum $25(\mathrm{OH})$ vitamin D vitamini düzeyi ile demografik özellikleri, enflamasyon belirteçleri düzeyleri ve hastanede yatış süresi arasındaki ilişki araştırıldı.
İstatistiksel analizler için SPSS (Statistical Package for Social Sciences) for Windows 21 programı kullanıldı. Değişkenlerin normal dağılıma uygunluğu görsel (histogram ve olasılık grafikleri) ve analitik yöntemlerle (Kolmogorov-Smirnov/Shapiro- Wilk testleri) incelendi. Tanımlayıcı istatistikler kategorik değişkenler için sayı ve yüzde olarak, normal dağılan sürekli değişkenler için ortalama \pm standart sapma, normal dağılmayan sürekli değişkenler için ortanca (minimum-maksimum) verilerek yapıldı. Kategorik değişkenlerin karşılaştırılmasında Pearson Ki-kare testi kullanıldı. Değişkenler gruplar arasında Student's $T$ testi ve Mann-Whitney $U$ testi kullanılarak karşılaştırıldı. $p$ değerinin 0.05 'in altında olduğu durumlar istatistiksel olarak anlamlı olarak kabul edildi.

\section{BULGULAR}

Çalışmaya ortanca yaşı 4 yaş ( 1 ay -17 yaş) olan 65'i (\%61.9) erkek (E/K:1,6) toplam 105 hasta dahil edildi. Yirmi dokuz $(\% 27,6)$ 1 yaşından küçük, 34 hasta $(\% 32,4)$ 1-5 yaş arasında ve 42 hasta (\%40) 5 yaşından büyük idi. Yirmi dokuz $(\% 27,6)$ hasta yatırılarak, $76(\% 72,6)$ hasta ayaktan takip edildi. Hastaların 44'ü viral akut alt solunum yolu enfeksiyonu, 61 'i bakteriyel akut alt solunum yolu enfeksiyonu tanısı ile izlenmiştir. Yatırılarak izlenen 29 hastanın 18 (\%62,1)'i 1 yaşından küçüktü. Hastanede yatış süresi ortanca değeri 7 gün (dağılım:3-19 gün) olarak saptandı. Elli sekiz $(\% 55,2)$ hastanın ilk kez akut ASE tanısı aldığı, 47 hastanın $(\% 44,8)$ hastanın daha önce geçirilmiş akut ASE öyküsü olduğu öğrenildi. Serum $25(\mathrm{OH})$ vitamin D düzeyi hastaların 63 'ünde düşük (<20 ng/mL), 42'sinde normal ( $\geq 20 \mathrm{ng} / \mathrm{mL}$ ) olarak saptandı. Yirmi dört $(\% 22,9)$ hastanın serum $25(\mathrm{OH})$ vitamin D düzeyi $<12 \mathrm{ng} / \mathrm{mL}, 37(\% 35,2)$ hastanın $12-20 \mathrm{ng} / \mathrm{mL}$ arasında, $44(\% 41,9)$ hastanın $>20 \mathrm{ng} / \mathrm{mL}$ olarak saptandı.

Bakteriyel akut alt solunum yolu enfeksiyonu tanısı olan hastalarda, viral akut alt solunum yolu enfeksiyonu tanısı alan hastalara göre, serum ortanca $25(\mathrm{OH})$ vitamin D düzeyi daha düşük saptanmıştır [sırasıyla: 14,6 ng/mL (5,1-121,4); 29,6 ng/ $\mathrm{mL}(1,7-87,7)(p<0,001)]$. Bakteriyel akut alt solunum yolu enfeksiyonu $(\% 80,3)$ tanısı olan hastalarda, viral akut alt solunum yolu enfeksiyonu $(\% 31,8)$ tanısı alan hastalara göre, vitamin D eksikliği daha sık olarak saptanmıştır $(p<0,001)$.

Bir yaşından küçük 29 hastanın 5'inin $(\% 17,2)$ serum $25(\mathrm{OH})$ vitamin D düzeyi $<12 \mathrm{ng} / \mathrm{mL}$, 4'ünün $(\% 13,8) 12-20 \mathrm{ng} / \mathrm{mL}$ arasında, 20'sinin (\% 69) $>20 \mathrm{ng} / \mathrm{mL}$ olduğu saptandı. Bir- beş yaş arası 34 hastanın 4'ünün $(\% 11,8) 25(\mathrm{OH})$ vitamin D düzeyi <12 $\mathrm{ng} / \mathrm{mL}, 11^{\prime}$ inin $(\% 32,4) 12-20 \mathrm{ng} / \mathrm{mL}$ arasında, 19'unun (\%55,9) $>20 \mathrm{ng} / \mathrm{mL}$ olduğu saptandı. Beş yaşından büyük 42 hastanın $15^{\prime}$ inin $(\% 35,7)$ serum $25(\mathrm{OH})$ vitamin $D$ düzeyi $<12 \mathrm{ng} / \mathrm{mL}$, 22 'sinin $(\% 52,4) 12-20 \mathrm{ng} / \mathrm{mL}$ arasında, $5^{\prime}$ inin $(\% 11,9)>20 \mathrm{ng} /$ $\mathrm{mL}$ olduğu saptandı (Tablo 1 ).

Akut ASE nedeniyle yatırılarak izlenen 29 hastanın 14'ünde $(\% 48,3)$ serum $25(\mathrm{OH})$ vitamin D düzeyi $<20 \mathrm{ng} / \mathrm{mL}$ olarak bulundu. Serum $25(\mathrm{OH})$ vitamin D düzeyinin $<20 \mathrm{ng} / \mathrm{ml}$ olmasının hastaneye yatış riskini 0,35 kat ( $p=0.048$, güven aralığı:0.12-0.9) arttırdığı saptandı. Yatan hastaların 12'si $(\% 41,4)$ kış mevsiminde, $15^{\prime} i(\% 51,7)$ ise ilkbahar mevsiminde yatırılmışt. Serum 25 $(\mathrm{OH})$ vitamin D düzeyi $<20 \mathrm{ng} / \mathrm{mL}$ olan 63 hastanın 27'sinin 
Tablo 1: Yaş gruplarına göre serum $25(\mathrm{OH})$ vitamin D düzeylerinin değişimi.

\begin{tabular}{|c|c|c|c|c|}
\hline & $\begin{array}{l}<1 \text { yaş } \\
(n=29)\end{array}$ & $\begin{array}{l}1-5 \text { yaş } \\
(n=34)\end{array}$ & $\begin{array}{l}>5 \text { yaş } \\
(n=42)\end{array}$ & p değeri \\
\hline \multicolumn{5}{|l|}{ Cinsiyet $^{*}$} \\
\hline Erkek & $19(65,5)$ & $21(61,8)$ & $25(59,5)$ & 0,70 \\
\hline $\mathrm{K} ı \mathrm{z}$ & $10(34,5)$ & $13(38,2)$ & $17(40,5)$ & \\
\hline \multicolumn{5}{|l|}{ Başvuru mevsimi ${ }^{*}$} \\
\hline Kış & $10(34,5)$ & $22(64,7)$ & $13(31)$ & \\
\hline İlkbahar & $17(58,6)$ & $9(26,5)$ & $15(35,7)$ & \\
\hline Sonbahar & $1(3,4)$ & $2(5,9)$ & $7(16,7)$ & \\
\hline Yaz & $1(3,4)$ & $1(2,9)$ & $7(16,7)$ & \\
\hline Vitamin D eksikliği* $<12 \mathrm{ng} / \mathrm{mL}$ & $5(17,2)$ & $4(11,8)$ & $15(35,7)$ & $<0,001$ \\
\hline Vitamin D yetersizliği* (12-20 ng/mL) & $4(13,8)$ & $11(32,4)$ & $22(52,4)$ & \\
\hline Normal serum $25(\mathrm{OH})$ vitamin D düzeyi ${ }^{*}>20 \mathrm{ng} / \mathrm{mL}$ & $20(69)$ & $19(55,9)$ & $5(11,9)$ & \\
\hline \multicolumn{5}{|l|}{ Hastaneye yatış ${ }^{*}$} \\
\hline Var & $18(62,1)$ & $8(23,5)$ & $3(7,1)$ & $<0,001$ \\
\hline Yok & $11(37,9)$ & $26(76,5)$ & $39(92,9)$ & \\
\hline \multicolumn{5}{|l|}{ Tekrarlayan akut alt solunum yolu enfeksiyonu* } \\
\hline Var & $15(48,3)$ & $17(50)$ & $15(35,7)$ & 0,30 \\
\hline Yok & $14(51,7)$ & $17(50)$ & $27(64,3)$ & \\
\hline
\end{tabular}

*Değerler $\mathrm{n}(\%)$ olarak verilmiştir, **Değerler ortanca (minimum-maksimum) olarak verilmiştir.

$(\% 42,9)$ kış mevsiminde, 23'ünün $(\% 36,5)$ ilkbahar mevsiminde hastaneye başvurduğu gözlendi. Tekrarlayan akut ASE öyküsü olan 47 hastanın 30'unda $(\% 63,8)$ serum $25(\mathrm{OH})$ vitamin D düzeyi $<20 \mathrm{ng} / \mathrm{mL}$ olarak saptandı. Tekrarlayan ASE tanısı ile izlenen 47 hastanın 17'sinin $(\% 36,2)$ kış mevsiminde, 10'unun $(\% 21,3)$ ilkbahar mevsiminde başvurduğu gözlendi (Tablo 2 ).

Tablo 2: Çalışmaya dahil edilen $\mathbf{1}$ ay $\mathbf{- 1}$ yaş aralığındaki hastaların doğdukları mevsime göre alt solunum yolu enfeksiyonu tanı anındaki serum $25(\mathrm{OH})$ vitamin D düzeylerinin değişimi.

\begin{tabular}{lc}
\hline Mevsimler & Serum $25(\mathrm{OH})$ vitamin D düzeyi $^{*}$ \\
\hline Kış & $26,9(1,7-87,7)$ \\
Illkbahar & $36,3(2,7-63,2)$ \\
Sonbahar & $35(2,8-55,1)$ \\
Yaz & $41,4(12,9-57,8)$ \\
\hline
\end{tabular}

*Veriler ortanca (minimum- maksimum) olarak verilmiştir.
Kız hastaların ortanca $25(\mathrm{OH})$ vitamin D düzeyi [ortanca: 14,9 $\mathrm{ng} / \mathrm{mL}(1,7-105,4)]$ erkek hastalara [20,2 ng/mL (2,7-121,4)] göre daha düşük saptandı $(p=0,07)$. D vitamini eksikliği 5 yaşından büyük hastalarda $(\% 88,1), 5$ yaşından küçük hastalara $(\% 41,3)$ göre istatistiksel olarak anlamlı düzeyde daha sık saptandı $(p<0,001)$.

Bir yaşından küçük 29 hastanın 9 (\%31)'u kış mevsiminde doğmuştu ve kış mevsiminde doğanlarda tanı anında ortanca serum $25(\mathrm{OH})$ vitamin D düzeyleri [26,9 ng/mL $(1,7-87,7)]$, diğer mevsimlerde doğan 1 yaşından küçük hastalara [ilkbahar, yaz ve sonbahar mevsimi sırasıyla $36,3 \mathrm{ng} / \mathrm{mL}(2,7-63,2), 41,4 \mathrm{ng} / \mathrm{mL}$ $(12,9-57,8)$ ve $35 \mathrm{ng} / \mathrm{mL}(2,8-55,1)]$ göre daha düşük saptandı. Bir yaşından küçük ve akut ASE nedeni ile yatırılarak tedavi edilen hastaların serum ortanca $25(\mathrm{OH})$ vitamin $D$ düzeyi $[25,9$ $\mathrm{ng} / \mathrm{mL}(1,7-87,7)]$, ayaktan tedavi edilen 1 yaşından küçük hastalarınkinde $[42,1 \mathrm{ng} / \mathrm{mL}(16,6-62,6)]$ göre daha düşük bulundu $(p=0,035)$ (Tablo 3).

Tablo 3: Yatarak ve ayaktan takip edilen hastaların yaş gruplarına göre serum 25(OH) vitamin D düzeylerinin değişimi.

\begin{tabular}{lccc}
\hline Yaş grubu & Yatan hastalar & Ayaktan hastalar & p değeri \\
\hline $\mathbf{0 - 1}$ yaş & $25,9(1,7-87,7)$ & $42,1(16,6-62,6)$ & $\mathbf{0 , 0 3 7}$ \\
$\mathbf{1 - 5}$ yaş & $30,5(15,2-64,8)$ & $20,5(6,6-121,4)$ & 0,088 \\
$\mathbf{> 5}$ yaş & $10,7(7,6-11,6)$ & $14,6(5,1-105,4)$ & 0,083 \\
\hline
\end{tabular}

Veriler ortanca (minimum-maksimum) olarak verilmiştir. 


\section{TARTIŞMA}

Pnömoni 5 yaş alt çocuklarda mortalitenin en sık nedenidir. Uygun, güvenli ve ulaşılabilir önlemler sayesinde pnömoniye bağlı çocuk ölümleri 1981 de 4 milyon iken 2013 yıllarında 1 milyona düşmüştür, ancak pnömoni hala tüm dünyada tüm çocuk ölümlerinin neredeyse \%20'sinin nedenidir (10). Çocukluk çağındaki tüm pnömoni olgularının 3/4'ü kaynakları kısıtlı yalnızca 15 ülkede görülmektedir. Afrika ve Asya ülkeleri gibi 5 yaş alt çocuk ölümlerinin \%70'inin gerçekleştiği ülkelerde, önlenebilir çocuk ölümlerinin ikinci sıklıktaki nedeni pnömonilerdir (11). Bizim çalışmamızda da akut alt solunum yolu enfeksiyonu tanısı konan hastaların \%63'ü beş altı hasta grubunda saptanmıştır.

Bu çalışmada akut ASE nedeniyle tedavi edilen 105 çocuk hastanın demografik verileri, klinik bulguları ve $25(\mathrm{OH})$ vitamin D düzeyleri değerlendirildi. Hastaların \%60'inin serum $25(\mathrm{OH})$ vitamin $D$ düzeyi düşük düzeyde bulundu. $25(\mathrm{OH})$ vitamin $D$ düzeyleri, kız hastalarda erkek hastalara göre, hastanede yatrılarak tedavi gören hastaların ayaktan tedavi edilen hastalara göre, bakteriyel akut alt solunum yolu enfeksiyonu olan hastalarda viral akut alt solunum yolu enfeksiyonu olanlara göre ve kış mevsiminde doğan 1 yaşından küçük hastalarda diğer mevsimlerde doğan 1 yaşından küçük hastalara göre daha düşük saptandı. Serum $25(\mathrm{OH})$ vitamin D düzeyinin $<20 \mathrm{ng} / \mathrm{ml}$ olmasının hastanede yatış riskini istatistiksel olarak anlamlı düzeyde arttırdığı saptandı. Türkiye'de 12389 erişkinde yapılan bir çalışmada hem kadınlarda hem erkeklerde 25-OH D düzeyleri bizim çalışma sonuçlarımızla uyumlu bir şekilde, kış mevsiminde en düşük, yaz mevsiminde en yüksek düzeyde bulunup, kadınlarda \%78'i erkeklerin de \%73'ünde serum 25(OH)vitamin D düzeyi $<20 \mathrm{ng} / \mathrm{mL}$ olarak saptanmıştır (12).

Pnömoni tanılı 40 hasta, 40 kontrol grubunun dahil edildiği çocuklarda yapılan bir başka çalışmada, serum $25(\mathrm{OH})$ vitamin D vitamini düzeyi pnömoni tanılı hastalarda, kontrol grubuna göre istatistiksel anlamlı olarak düşük saptanmıştır (13). Ancak bu bahsedilen çalışmada, bizim çalışmamızdan farklı olarak başvuru mevsimi, tekrarlayan ASE öyküsü kaydedilmemiştir.

Çin'de 77 toplum kökenli pnömoni tanılı çocuk hastada yapılan bir çalışmada, hastaların \%71,4'ünde vitamin D eksikliği saptanmış, yaş ile beraber vitamin D eksikliğinin sıklığının arttğı belirtilmiştir (14). Bizim çalışmamızda da vitamin D eksikliği istatistiksel anlamlı olarak en sık 5 yaş üstü çocuklarda görülmüştür.

Bangladeş'te, ASE nedeniyle yatırılan süt çocuklarında yapılan bir çalışmada kontrol grubuna göre serum $25(\mathrm{OH})$ vitamin D düzeyi daha düşük olarak saptanmıştır (15). Bizim çalışmamızda da 1 yaş altında yatan hastalarda, ayaktan takip edilenlere göre serum $25(\mathrm{OH})$ vitamin D düzeyi daha düşük olarak saptanmıştır.

Literatürden 5660 hastanın dahil edildiği bir metaanaliz sonuçlarına göre günlük oral D vitamini desteğinin solunum yolu enfeksiyonu riskini iststistiksel anlamlı olarak azalttı̆ı saptanmıştır (16). Hindistan' da yapılan bir metaanaliz sonuçlarına göre de vitamin D desteğinin, plaseboya göre solunum yolu enfeksiyon sıklığını, özellikle çocuk hastalarda, istatistiksel anlamlı olarak azalttı̆ı saptanmıştır (17).
$25(\mathrm{OH})$ D vitamini primer olarak kalsiyum homeostazı ve kemik metabolizmasından sorumlu olmakla birlikte; aktif $25(\mathrm{OH}) \mathrm{D}$ vitaminine ait reseptörler, timus ve lenfositler gibi birçok dokuda tanımlanmıştır (18). D vitamininin dendritik hücrelerde maturasyon, diferansiyasyon ve migrasyonu sağlaması; T1 hücrelerinde aktivasyonu suprese etmesi; regulatör $\mathrm{T}$ hücrelerini stimule etmesi; myeloid ve eritroid seri hücrelerini aktive etmesi önemli bir immunmodülator olduğunu göstermektedir. Ülkemizde Doğan ve arkadaşları tarafindan yapılan bir çalışmada pnömoni tanısı alan ve serum $25(\mathrm{OH})$ D vitamin düzeyi düşük olan vakalarda serum CD4 düzeyi ve B lenfosit sayısının düşük olduğu tespit edilmiştir. Tedavi bitiminde serum CD4 düzeyinin arttı̆̆ı saptanmıştır (19).

Çalışmamızda bakteriyel akut alt solunum yolu enfeksiyonu olan çocuk hastalarda, viral akut alt solunum yolu enfeksiyonu olanlara göre serum $25(\mathrm{OH})$ vitamin D düzeyi daha düşük saptanmıştır. Yapılan çalışmalar hepatit, influenza, COViD-19 ve HIV enfeksiyonlarında, düşük vitamin $D$ düzeyinin viral enfeksiyon riskini arttırdığını savunmaktadır (20). Bir metanaliz sonuçlarına göre vitamin D eksikliği (serum $25(\mathrm{OH}) \mathrm{D}<20 \mathrm{ng} / \mathrm{mL}$ ) olan hastalarda toplum kökenli pnömoni riskinin anlamlı arttğı sonucuna varılmıştr (odds ratio (OR)=1,64, \%95 (Cl): 1.00, 2,67) (21).

Bu çalışmanın retrospektif bir çalışma olması, vitamin eksikliklerine neden olabilecek ek risfkfaktörlerinin kaydedilmemiş olması, özellikle 1 yaş alt grupta annenin vitamin düzeylerinin ve beslenme durumunun kaydedilmemiş olması çalışmanın kısıtlılıkları arasındadır.

Ülkemizde 2005 yılından başlayarak D vitamini eksikliğini önlemek amacıyla günde 400 IU D vitamini desteği 0-12 ay arasında tüm bebeklere uygulanmaktadır. Türkiye gibi gelişmekte olan ülkelerde sosyoekonomik düzeyin düşük oluşu, kişi başına düşen milli gelirin az olması, karbonhidrattan zengin, proteinden fakir beslenme, nüfus ve aile planlaması gibi birçok neden pnömoninin beş yaş alt çocuklarda en sık ölüm nedeni olmasını açıklayabilir. Pnömoni gelişmesini sağlayan birçok etken bulunmakla beraber, bunların önlenebilir olanları bizim için önemlidir. ASE tanısıyla izlenen hastalarda D vitamini düzeylerine bakılması, eksiklik saptanan hastalara vitamini desteğinin yapılması ile tekrarlama riskini ve yatış ihtiyacını azaltılabilecektir.

Etik Komite Onayı: Ankara Keçiören Eğitim ve Araştırma Hastanesi Etik Kurulu'ndan onay alınmıştır (18.6.2019/43278876-929).

Bilgilendirilmiş Onam: Katılımcılardan bilgilendirilmiş onam alınmıştır.

Hakem Değerlendirmesi: Dış bağımsız.

Yazar Katkıları: Çalışma Konsepti/Tasarım- K.A.; Veri Toplama- K.A.; Veri Analizi/Yorumlama- K.A., A.Ç.T.; Yazı Taslağı- K.A.; İçeriğin Eleştirel İncelemesi- A.Ç.T.; Son Onay ve Sorumluluk- K.A., A.Ç.T.

Çıkar Çatışması: Yazarlar çıkar çatışması beyan etmemişlerdir.

Finansal Destek: Yazarlar finansal destek beyan etmemişlerdir.

Ethics Committee Approval: This study was approved by the ethics 
committee of Ankara Keçiören Training and Research Hospital (18.6.2019/43278876-929).

Informed Consent: Written consent was obtained from the participants.

Peer Review: Externally peer-reviewed.

Author Contributions: Conception/Design of Study- K.A.; Data Acquisition- K.A.; Data Analysis/Interpretation- K.A., A.Ç.T.; Drafting Manuscript- K.A.; Critical Revision of Manuscript- A.Ç.T.; Final Approval and Accountability- K.A., A.Ç.T.

Conflict of Interest: Authors declared no conflict of interest.

Financial Disclosure: Authors declared no financial support.

\section{KAYNAKLAR/REFERENCES}

1. Burstein R, Henry NJ, Collison ML, Marczak LB, Sligar A, Watson $S$, et al. Mapping 123 million neonatal, infant and child deaths between 2000 and 2017. Nature 2019;574(7778):353-8.

2. Rudan I, Boschi-Pinto C, Biloglav Z, Mulhollandd K, Campbell H. Epidemiology and etiology of childhood pneumonia. Bulletin of the World Health Organization 2008;86:408-16.

3. Institute of Medicine (U.S.), Committee to review dietary reference Intakes for vitamin $\mathrm{d}$ and calcium. dietary reference intakes: calcium and vitamin D. Washington, D.C.: National Academies Press; 2011.

4. World Health Organization/Food and Agriculture Organization (WHO/FAO). Vitamin and mineral requirements in human nutrition: report of a joint FAO/WHO expert consultation. Bangkok, Thailand; 2004;9:21-30.

5. Holick MF. The vitamin D deficiency pandemic: Approaches for diagnosis, treatment and prevention. Rev Endocr Metab Disord. 2017; 18:153-65.

6. Opinder S. Understanding vitamin D deficiency, Age and Ageing. 2014;43(5):589-91.

7. Pludowski P, Holick MF, Pilz S, Wagner CL, Hollis BW, Grant WB, et al. Vitamin $D$ effects on musculoskeletal health, immunity, autoimmunity, cardiovascular disease, cancer, fertility, pregnancy, dementia and mortality- a review of recent evidence. Autoimmun Rev 2013;12:976-89.

8. Munns CF, Shaw N, Kiely M, Specker BL, Thacher TD, Ozono K, et al. Global consensus recommendations on prevention and management of nutritional rickets. Horm Res Paediatr. 2016;85:83106.
9. Charoenngam N, Holick MF. Immunologic Effects of Vitamin D on Human Health and Disease. Nutrients 2020;15:12(7):2097. doi: 10.3390/nu1207209.

10. McAllister DA, Liu L, Shi T, Chu Y, Reed C, Burrows J, et al. Global, regional, and national estimates of pneumonia morbidity and mortality in children younger than 5 years between 2000 and 2015: a systematic analysis. Lancet Glob Health 2019;7(1):47-57.

11. Walker CLF, Rudan I, Liu L, Nair H, Theodoratou E, Bhutta ZA, et al. Global burden of childhood pneumonia and diarrhoea. Lancet 2013;381:1405-16.

12. Telo S, Kaman D , Akgöl G. Elazığ İlinde D Vitamini Düzeylerinin Yaş, Cinsiyet ve Mevsimlere Göre Değişimi. Fırat Tı.p Derg/Firat Med J 2017;22(1):29-33.

13. Ünal Ü, Özkan B, Çayır A, Kaya A, Orbak Z. Serum $25(\mathrm{OH})$ D vitamin düşüklüğü çocukluk çağı pnömonileri için bir risk faktörü müdür? Dicle Tıp Dergisi 2012;39(4):531-5.

14. Huang Y, Fu L, Yang Y. Age-Related Vitamin D Deficiency is associated with the Immune response in children with communityacquired pneumonia. J Nutr Sci Vitaminol 2017;63(1):1-7.

15. Roth DE, Shah R, Black RE, Baqui AH. Vitamin D status and acute lower respiratory infection in early childhood in Sylhet, Bangladesh. Acta Paediatr 2010;99(3):389-93.

16. Cannell JJ, Vieth R, Umhau JC, Holick MF, Grant WB, Madronich $S$, et al. Epidemic influenza and vitamin D. Epidemiol Infect 2006;134(6):1129-40.

17. Charan J, Goyal JP, Saxena D, Yadav P. Vitamin D for prevention of respiratory tract infections: A systematic review and metaanalysis. J Pharmacol Pharmacother 2012;3(4):300-3.

18. Pasquali M, Mandanici G, Conte C, Muci ML, Mazzaferro S. Understanding the different functions of vitamin D. G Ital Nefrol 2009;26(46):53-7.

19. Doğan M, Erol M, Cesur Y, Arı Yuca S. The effect of 25-hydroxyvitamin D3 on the immunsystem. J Pediatr Endocrinol Metab 2009:22(10):929-35.

20. Cepeda SJ, Zenteno AD, Fuentes SC, Bustos BR. Vitamina D enfermedades respiratorias pediátricas [Vitamin $D$ and pediatrics respiratory diseases]. Rev Chil Pediatr 2019;90(1):94-101.

21. Martineau AR, Jolliffe DA, Greenberg L, Aloia JF, Bergman $P$, Dubnov-Raz $G$, et al. Vitamin D supplementation to prevent acute respiratory infections: individual participant data meta-analysis. Health Technol Assess 2019;23(2):1-44. 